\title{
Fundamentalism, Boko Haram Movement and Socio- Economic Development in North-Eastern Zone of Nigeria
}

\section{Bamidele Rasak \\ Olubukoye Oye \\ Joseph Adeniyi}

Department of Sociology

Landmark University, Omu-Aran, Nigeria
DOI:10.36108/NJSA/8102/61(0270)

\begin{abstract}
There are divergent perspectives on the effect of the activities of Boko Haram in Nigeria. This study examined fundamentalism and socio-economic development in the North-Eastern zone of Nigeria with particular reference to the Boko Haram movement. Social Movement Theory was employed as theoretical framework for explaining the implication of Boko Haram insurgency for socioeconomic development of Northeast Nigeria. Secondary data were collected to elicit information for analysis. Boko Haram as a sect had resorted to the use of violence. This study shows that the rise in radical movements is mainly explainable by poor socio-economic infrastructures, poor governance and poverty that catalyse rapid increase in the membership of the group.
\end{abstract}

Keywords: Fundamentalism, social movement, Islamization, socio-religious group

\section{Introduction}

Fundamentalism refers to a sect or movement within a religion that emphasizes a rigid adherence to what it conceives of as the fundamental principles of its faith, usually resulting in a denouncement of alternative practices and interpretations (Brasher, 2001: 17). There are fundamentalist sects in almost all of the world's major religions, including Christianity, Islam, Hinduism and Judaism. Cross-culturally, fundamentalism is characterized by a cluster of common attributes including a literal interpretation of scripture, a suspicion of outsiders, a sense of alienation from the secular culture, a distrust of liberal elites, and the belief in the historical accuracy and inerrancy of their own interpretation of their religious scriptures. Additionally, religious fundamentalists are often politically active and may feel that the state must be subservient to God (Brasher, 2001: 17). Although, it believed that fundamentalism was initially at the level of advocacy, its impact on violent fundamentalist groups could not be wished away, yet the approach of the same government whose legitimacy is being questioned to the problem of Islamic fundamentalism could at best be described as lackadaisical. This brings into focus the issue of fundamentalism, Boko Haram movement and socioeconomic development in North-eastern zone of Nigeria. 


\section{Problem Statement}

Boko Haram activities was described by US intelligence agents in November 2011-as a local salafist group attacking Christians and local police stations with matchet and poison tipped arrows in Nigeria's north-eastern states (Ezema, 2013: 14, c.f., Campbell, 2011). According to him:

Boko Haram is a way of thinking, it is politically driven, and they are loosely organized grassroots insurrection against not only the Abuja government but the traditional Muslim establishment as well. (Ezema, 2013: 14, c.f., Campbell, 2011)

After nearly a decade of violence, the Nigerian government still does not have an effective strategy for dismantling the group (Ezema, 2013: 15). The terrorist organization preys on the disillusioned Muslims of the north, who are fed up with corruption. And have few economic opportunities, Nigeria is a heterogeneous country divided by two religious beliefs aside traditional religion. The northern half of the country is almost completely Muslim (50 per cent of the total Nigerians population) and the southern half is mostly dominated by Christians ( 40 per cent of the total Nigerians population).

Originating in the Muslim dominated northern region of the country, the movement rejected everything deemed western. The activities of these groupsBoko Haram grew in ranks by taking advantages of the widespread anger in the north over the country's gap. In the north, 72 percent of the population lives below the poverty line, compared to only 22 percent in the southern part (Ezema, 2013: 16). The political goal of Boko Haram sect is to create an Islamic nation in the twelve northern states of Nigerians, eventually, spreading to the rest of the country. From its inception Boko Haram viewed Nigeria as a state or a country running by non-believers and made the government its main target, even when the country had a Muslim president (Ezema, 2013: 16). Therefore, this study seeks to find the following: Does the Boko Haram sect as a fundamentalist movement have any implication on the socio-economic development of the North-eastern zone of Nigeria?

\section{Brief Review of Literature}

This aspect of the study covers the literature review and the theoretical framework that was used in this study.

\section{Conceptualizing the term Fundamentalism}

There is the sociological meaning of "fundamentalism" and "fundamentalist." For the past three decades sociologists have been defining "fundamentalism" as "religious anti-modernism." Allegedly, anyone who is against modernity for religious reasons is a "fundamentalist" (Woodberry \& Smith, 1998: 25). But there are some problems with that. First, it's simply too broad. Second, many fundamentalists, historically, were consciously or unconsciously influenced by modernity. Third, fundamentalists are often the most willing to make religious use of modern technological innovations. Fourth, many spiritually-minded 
postmodern people could be called anti-modern in certain ways but could not rightly be called fundamentalists (Ruthven, 2005: 3).

Historically, the term "fundamentalism" was first used in the early 1900s among American Protestant Christians who strove to return to the "fundamentals" of Biblical faith, and who stressed the literally interpreted Bible as fundamental to Christian life and teaching (Aldon, 1996: 29). The subsequent growth of religious fundamentalism in the twentieth century has been tied to the perceived challenge that both secularism and liberal values pose to traditional religious authorities, values and theological truth claims Fundamentalism appeals to religious believers who feel threatened by the encroachment of liberal values into traditionally religious spheres (Maryjane, 1996: 86). They feel besieged by secular culture which they regard as immoral and godless.

In the early 1970s 'fundamentalist' was used to refer only to those groups that also engaged in political or militant behaviour (Christian, 1996:9) and for a while the term looked set to exclusively refer to Islamic groups. Knowing the ambiguities, many academics are wary of the word. Keddie (1998: 696) opined that it should only be use to describe movements that oppose modernity, and therefore only groups that have arisen after 1800-1850 CE. It has instead grown to describe a huge variety of religious groups, often simply being a code-word for "a group we don't like" (Quintan, 2006: 207) like the word "cult".

The current state of Islamic fundamentalism in Nigeria as it is manifested in Boko Haram is a product of Nigerian societal and economic problems or is tied to the broader Islamic revival as marked by the rise of al Qaeda and its derivative groups. Perhaps as it often is with complex societal insurgencies, it is a combination of all of these factors. An analysis of existing literature exposes many familiar themes: the presence of oil, corrupt government officials, a history of Islamic prominence; a colonial legacy, including drawing borders with little importance given to ethnic or religious history; and a rejecting of Western influence (Ezema, 2013: 16).

A major challenge faced by the central government in Nigeria since the return of civil rule in 1999 was the introduction of Sharia law in some states in northern Nigeria, with Zamfara blazing the trail. The law now operates in twelve of the nineteen northern states, with varying manifestations (Nmehielle, 2004: 730; Ostien, 2007). Going by constitutional provision, the adoption of Sharia law meant the existence of dual legal systems in those states, as well as the adoption of state religion, contrary to the provision of section 10 of the 1999 Constitution, which states expressly that "the Government of the Federation or of a State shall not adopt any religion as State Religion" (Federal Military Government, 1999).

But even at that, Boko Haram movement in particular criticized the limited application of Sharia and condemned the insincerity of the state governors, whom it accused of politicizing it. This explains why the full implementation of Sharia not only in the north, but the whole of the country, 
was the advertised cause of the jihad. Like Boko Haram, but for different reasons, the federal government under Olusegun Obasanjo condemned the adoption, which it saw as unconstitutional, a political phenomenon that would soon "fizzle out" (Tell, 2001). One of the governors who introduced Sharia became the country's president and ruled until 5 May 2010, when he died; some of them are currently facing trial for corrupt practices while in office a vindication of sorts of the critics of Sharia adoption (The Guardian, 2003).

Viewed from a broader perspective, the adoption of Sharia appeared like an effort to pacify a section of Muslims who had consistently agitated against the secularity of the country, and perhaps were seen as a threat to the tenure of the political officeholders or a support base that could not be neglected on the basis of political calculation. The undue emphasis on religion as a basis for differentiation and mobilization accounts for this, but the measure appeared not strong enough to appease these elements which, when they would not embark on insurrection, would not check it before it degenerated, or feebly condemn it.

Legitimizing power by northern traditional rulers was an open door to Islamic fundamentalism from the start (Abimbola, 2010: 100). As far as Hickey (1984: 251) is concerned; this position or ambivalence of these elements was not dictated by the lack of belief in the extremists' position: the difference is over method, rather than ultimate aims.

The extremists insist on a unitary view of the society, which sees no difference between the state and religion, and they advocate making Nigeria an Islamic state, administered according to the principles of Sharia. For them, all Muslims belong to the umma (community), and the idea of a secular state is atheistic or syncretistic (Dickinson, 2007). Apart from challenging the Muslim affirmation of religious principles, especially Sharia, the imposition of secularity according to them amounts to a cultural affront on a significant portion of the population and reduces them to the status of second-class citizens.

Although this view is claimed to be a Quranic injunction, it does not enjoy popular acceptance among liberal Muslims, who maintain that such a view does not imply the need for Islamization of Nigeria, nor does it endorse nonacceptance of the constitutional provision of the secularity of the state (Ibrahim, 1998: 66; Ilesanmi, 2001: 529; Imo, 1995). Pertinent also is the failure of governance and its labeling as a tyranny that must be discarded, prompting the leadership and members of the movements to risk death to pursue what they consider the path to Islamic justice (Danjibo, 2009: 29). Even before the Boko Haram and Maitatsine riots, fundamentalist groups like the Shiite had advocated a fanatical position that, in a wider political sense, meant the rejection of the secular authority ab initio (Suleiman, 2009: 19).

\section{Reasons for Fundamentalist Activities}

Differences in religions have been responsible for deeper divisions within communities than any other source of conflict. This assertion occupies a sad, 
but remarkable position in the history of the world. A number of factors may be responsible for this.

\section{Religious Intolerants}

Religion may become a divisive force when a society is faced with conflicting and mutually intolerant religions. Christianity and Islam are at one stage or another involved in this type of conflict, for example, the clash between Muslims and Christians in the days of the latter (Christians) penetration into the Mediterranean world. It was this confrontation that later culminated into the Christian crusades, an attempt by the Christians to regain the control of Jerusalem. This crusade represented the reaction of Christian Europe against Muslim Asia (Osaretin, 2015: 3).

It was on that record that the spread of Islam into Syria and Asia Minor, as well as Spain and Sicily in Europe by jihad had infuriated the European Christian (i.e. Byzantine). The Christians captured Jerusalem back from Muslims on July 15, 1099 after it had been in Muslims hands for 61 years. Muslims took back Jerusalem on October 2, 1187 some 88 years after the Christians gained it. This kind of cat and dog existence continued among the Christians and Muslims until the creation of the Independent State of Israel on 14th May, 1948 (Osaretin, 2015: 3).

This was the crux of the crises in the Middle East. Another cause of religious fanaticism is diverse interpretation of doctrine within the same religion. The example that readily comes to mind is the Protestant Reformation and the various religious wars that ensued in Europe. For example, French wars of religion 1562-1610; the Netherlands revolt 15781609, and the thirty years war between Catholic and Protestant States in Europe 1618-1648 (Armstrong, 2001: 58).

Muslims also have this type of mutually intolerant interpretation of the same religion (Armstrong, 2001). Less than three decades following prophet Mohammed's death, there arose many Muslim sects, among which were the Kharijites, who held that the leadership of the Muslim community neither belonged to some branch of Mohammed's family, nor to a certain Arab tribe, but to the one best qualified for it (Armstrong, 2001: 58).

In Nigeria, two major issues have succeeded in causing religious intolerance. They are Secularism in the Nigerian State and Indoctrination of the Nigerian citizens. Secularism was the major debate during the Constituent Assembly in 1978 as regards Sharia Court of Appeal. Section 10 of the 1979 and 1999 constitutions say that "the Government of the Federation or of a State shall not adopt any religion as state religion". Section 35 of the same constitution declares that:

Every person shall be entitled to freedom of thought, conscience and religion including freedom to change his religion or belief and freedom ... to manifest and propagate his religion or belief in worship, teaching, practice and observation. (CFR, 1979, 1999: 35) 
In the opinion of Balogun (1988: 328), a critical examination of the Constitutional provision is improperly defined and loosely interpreted. To him, this has given way to inconsistencies. He questioned the rationale for funding Pilgrimage to Mecca and Jerusalem, and the establishment of a National Religious Council by a secular Nigerian State. Balogun (1988: 328) also identified a fundamental difference in organic religious socialization to state secularism between Islam and Christianity. To him, State secularism is a concept which asserts the principle of separation of the Church and State.

While Christians may support the concept, the Muslims, in accordance to the tenets of their faith, cannot be inclined to state secularism. To Balogun (1988: 328), this fundamental difference caused a series of time-bombs which nearly reached the point of explosion during the Organization of Islamic Conference (OIC) issue in Nigeria. He therefore suggested Re-interpretation and reworking of the Constitution in such a way that Nigeria would be recognized as a multi-religious state.

\section{Poverty}

Poverty is the deprivation of basic needs which commonly known as food, clothing, shelter healthcare and education. Nigeria is an underdeveloped country and poverty is one of the problems bedeviling the country. Nigeria is very rich in term of natural resources. Nigeria is one of the largest producer of oil in the world. The country is also blessed with vast arable land for agriculture and it is also rich in solid minerals (Omemma, 2012).

However, the country has been so bedevilled with bad leadership since independence that the country today despite her redness in natural resources, is one of the poorest countries in the world in terms of per capital income (Omemma, 2012). The level of Poverty is so high that one time Central Bank of Nigeria (CBN) Governor, Soludo (2007) said that poverty was an issue of the North. Also, it was opined that poverty is fueling Boko Haram and same vein, former president of US; Bill Clinton echoed the same view.

These realities are much more obvious in rural areas and slums. In these places, people die because they cannot afford \#500 to purchase needed medication or basic public health care (Soludo, 2007). Worse still, people around may not be able to help as they too may not be able to collectively raise that amount. It is a very obvious reality in today's Nigeria. The fundamental imperfection in the macroeconomic structure of Nigeria is unsustainable, and that our politics cannot crowd out the impending reaction to their unaddressed problem.

Karl Marx is popularly known for a truism which emphasizes our current reality, when he stated that religions is the opium of the poor, yet it is not only about religion but our historical cultural practices of deliberately putting people in a state of ignorance. Thus the greater the level of poverty, the higher the level of illiteracy and of course, more poverty, these dynamically reinforce each other. Accordingly, when a young man is poor and unemployed, he 
becomes a clean slate for any kind of brainwashing (The Nation, 2011). The brainwashing given to them provides a quasi-equivalent of employment and thus feels engaged in acting out what they have been brainwashed about. This is the kind of situation we find with Boko Haram phenomenon.

\section{Unemployment}

The problem of chronic youth unemployment is very evident in Nigeria. Every year thousands of graduate are turn out for where there are no jobs. Nigerians street are littered with youth hawkers who ordinarily would have found gainful employment in some enterprises, or would have demonstrated their skill and resourcefulness if there is enabling environment. Instead, the youth have now shifted their attention to terrorism (Adepegba, 2011). Unemployment describes the conditions of people who are without jobs. The international labour organization (ILO) (2008) defines unemployment, as number of the economically active population who is without work but available for and seeking for work. When the supply of labour outstrips the demand for labour, it causes joblessness and unemployment.

The presence of large army of unemployment youth in Nigeria is a clear case of failure of leadership to utilize abundant human and natural resources in the country to creates jobs that will engage the youths in production and meaningful economic activities (Adejumobi, 2011). The unemployed youths have become political thugs and blood-thirsty hoodlums at the disposal of the politicians. The point here is that when large numbers of youths are unemployed, their quest to survive may make them become willing tools in the hands of mavericks and disgruntled politicians who may want to use them for anti-social and clandestine political activities. The utilization of the unemployed youths to perpetuate ethno-religious clashes in the present democratic dispensation are well documented (Ibrahim, 1991: 115).

Put in context, unemployment is higher in northern Nigeria than its southern counterpart. Government statistics shows that the northern states have the higher proportion of uneducated Nigerians. If you link a lack of education and attendant lack of opportunities to high male youth population, you can imagine why northern Nigeria is actually a breeding ground for Boko Haram's recruits.

\section{Corruption}

It is a fact that there is high prevalence of corruption in Nigeria. According to Ezema (2013: 18), "the rise of Boko Haram in northern Nigeria has been simply because of the failure of successive Nigerian governments to curb corruption, deliver public services, generate economic opportunity, establish accountable securing institutions and engage communities both north and south in a more fully national polity". The severe wealth and infrastructural disparities and the failure of the Nigerian government to enact policies that would enable the different ethnic nationalities that make up the country to better govern themselves seems to accentuate the problem for a country ranked 
144 of the 177 countries ranked in the Corruption Perceptions Index 2013 (Transparency International, c.f. Ezema, 2013: 23).

\section{The advent and Ideology of Boko Haram movement in Nigeria}

Book Haram whose real name is Jama'atu Ahlis Sunna Lidda' Awati Wal Jihad (the Sunni Community for the propagation of the prophet's Teachings and Jihad), is a radical Islamic group founded in 2002 by Mohammed Yusuf in north-east Nigeria. The group is also active in other geographically contiguous states which include Cameroun, Chad and Niger. Estimates put its membership between 600 and 10,000 (Olagunju, 2011: 10, cf. Osaretin).

Although Boko Haram has been linked with al-Qaeda over the years, it expressed support for the Islamic State (IS) in 2014 and pledged formal allegiance on 7 March, 2015. In its early days, many observers saw the group as a social movement meant to articulate the collective interest of the poor (Olagunju, 2011: 10, cf. Osaretin 2015). Although Boko Haram was not a violent movement at its inception, it has killed more than 5,000 civilians between July 2009 and June 2014 (this includes at least 2,000 in the first half of 2014, in a series of coordinated attacks predominantly in north-east of Nigeria (Sergie \& Johnson, 2014).

The evolution of Boko Haram is a response to the socio-economic flux borne out of a combination of decades-long mismanagement and pervasive corruption in Nigeria (Olagunju, 2011: 10, cf. Osaretin 2015). Perhaps, this explains the adaptive nature of the group's methods and membership in the ever changing circumstances of the country's environmental ecology.

According to Pérouse de Montclos (2014), cf. Osaretin 2015:

This has allowed for multiple descriptions of the group to endure, bridging different narratives of terrorism, insurgency and criminality, where different drivers of conflict and instability have converged.

While it could be argued that the history of Nigeria is replete with the activities of Islamic sects, it is a fact that a multiplicity of domestic actors and interests combine within the complex political environment that the Nigerian represents to sustain the philosophy of these groups. For example, the criminality that drives the sectarian agenda of Boko Haram grew out of its confrontation with the Nigerian state (Osaretin, 2015). Thus, the group's mutation into a radicalized violent insurgent group with shades of cultist and criminal motivations was due to prolonged period of mishandled response by the Nigerian government and its security forces.

Originally a small group, Boko Haram with its grassroots appeal acted as a cohesive unit which retaliated to average killings of its members. For this reason and its rejection of Western education, the group is often compared to the Maitatsine movement of the 1970s and 1980s in northern Nigeria. The Maitatsine group, led by Mohammed Marwa condemned the reading of books 
other than the Quran. Unlike Marwa who claimed to be a prophet in the image of Usman Dan Fodio, Boko Haram's founding leader, Yusuf could pass for the leader of the underprivileged.

Nevertheless, some analysts view the group as an extension of the Maitatsine movement (Johnson, 2011). This stems from the belief that its ideology was inspired by the determined commitment to the eradication of heresies and the implementation of the Sharia legal codes in Nigeria. To achieve this aim, Boko Haram believes that it requires a change of political regime in Nigeria because a democratic and secular constitution contravenes and is an affront to the laws of Allah. Boko Haram conducted its operations relatively peacefully during the first seven years of its existence.

Although, there were repeated warnings on the potential danger of the group to the government, such warnings were ignored partly because the group was once used as a political leverage in the election of the then Born State governor, Sheriff Alimodu. The metamorphosis of Boko Haram into a terrorist group started with the investigation carried out by members of the Nigerian Police force in 2009 into its activities. Code name 'Operation Flush', on 26th July of the same year, security forces arrested nine Boko Haram members and confiscated weapons and bomb-making equipment.

Consequently, a joint military task force operation was launched against the group and by 30 July, more than 700 people had been killed (mostly Boko Haram member and police stations, prisons, government offices, schools and churches had been destroyed (Abimbola, 2010: 99). Subsequently, the leader of the group, Yusuf was arrested and died in custody. The Nigerian military repression of Boko Haram's in July 2009 uprising and the emergency rule imposed by government in Adamawa, Borno and Yobe states in north-eastNigeria since 2012 certainly contributed to an intensification of violence and the group's transformation into a terrorist group. Equally contributory was the extra-judicial killing of Mohammed Yusuf in police custody in July 2009 which led to the enthronement of the more radicalized members of the group headed by Abubakar Shekau (Abimbola, 2010: 99).

In fact, those who were initially interested in negotiation with the Nigerian government were killed by the security forces in an effort to crush the group entirely. This attempt by government sent the group underground while its leadership went into exile and made contact with foreign Jihadist groups. Boko Haram carried out its first terrorist attack in Borno state in January 2010 claiming the lives of four people. In June of the same year, its new leader Abubakar Shekau instructed members of the group to commence retaliatory target of security forces and traitors but to spare civilians.

This dramatic change of events was the watershed of a chain reaction of suicide attacks that extended beyond Borno State for the first time. In September, Boko Haram broke 105 of its members out of prison in Maiduguri along with over 600 other prisoners. This later transcended several areas of northern Nigeria. Since then, Boko Haram has increased the frequency and intensity of its attack with increased suicide bombings and assassinations. 
Many believe that Boko Haram is leading an armed insurgency against corruption, abusive security forces and economic disparity in northern Nigeria, and feeding off tension that have existed between Muslim dominated north and Christian dominated south of Nigeria. In 2011, with improved operational capabilities, Boko Haram launched series of attacks against both soft targets and security posts like the one in June, killing 6 police officers at the Abuja police headquarters (Abimbola, 2010: 99).

However, the groups attack on the United Nations building in Abuja in which 11 UN staff members died as well as 12 others, with more than 100 injured, seems to suggests that the group's ambition are broader than initially believed. The group carried out 115 attacks in 2011, killing 550. At the end of 2011, Boko Haram maintained a steady rate of attack with individuals, groups, security forces and religious leaders as prime targets.

The implementation of the emergency rule in Adamawa, Borno and Yobe states in Nigeria marked a turning point in Boko Haram insurgency. Few days after the state of emergency was declared, the group embarked on a series of small-scale attacks on Christians and 'strangers' (non-indigenes) resident in northern Nigeria. Members of the police force drafted in by government to protect fleeing 'southerner' became prime targets. In Kano, on 20 January, Boko Haram carried out a deadly assault on police building killing 190 (Abimbola, 2010: 112). Given the upsurge in the success recorded by the group against the security forces, many began to question the loyalty of the members of the Nigerian security force. This came to a head on 8 January 2012, when the Nigerian President Goodluck Jonathan announced that Boko Haram had, in fact, infiltrated the army and the police, as well as membership of the government.

Since 2009, the Joint Task Force (JTF) was deployed to north-eastern Nigeria to quell Boko Haram violence. Unfortunately, the role of and abuses by this security force conspired to worsen the dire security condition in the area. In addition to the failure of the JTF to protect lives and property, it lost the trust of the people (an important resource in the battle against the insurgent group), as communities were also abused by the armed forces. Also, the highhandedness with which the members of the JTF prosecuted the fight against the insurgency helped to diffuse membership of the group from urban centres to the rural areas, enhancing an increased collateral damage.

The year 2013 witnessed the introduction of a new dimension to its insurgent activities by Boko Haram. Early into the year, the conflict spilled over the national borders to involve all four geographically contiguous countries in the sub-region (namely Cameroun, Chad, Niger and Nigeria). Added to this innovation, is the fact that Boko Haram in association with its splinter group Ansani, was linked to a number of kidnappings. The group kidnapped on different occasions seven French taunts in north of Cameroun in February, a French priest and other eight French citizens and obtained ransom payments for their release. 
Furthermore, the increased insecurity in north-east Nigeria led the government to extend the state of emergency in May 2013. This development was met by increased tension in the three states affected (Adamawa, Borno and Yobe) as Boko Haram heightened the tempo of its insurgent activities. As such, the total number of internally displaced persons increased from 250,000 to 650,000 ; an increase of 309 per cent and thousands of others fled the country (Osaretin, 2015).

The most notorious act of Boko Haram so far took place in April 2014, when 276 girls from Chibok town in Borno state were kidnapped. Although over 50 of them managed to escape, the incident brought the group pervasive global attention. The girls' plight featured on "Bring Back Our Girls" posters all over the world. Within the same period, Boko Haram announced the formation of Islamic Caliphate which included Gwoza, a strategic town northeastern Nigeria. The town of Bama, 70 kilometres from Maiduguri was equally captured (increasing the reach of the new caliphate).

Despite the aggression of the Nigerian security forces against Boko Haram and suspected collaborators since 2009, the group continues to recruit new members. The upward trend in violence since then suggests that the more security forces have intervened, the worse the crisis has become. For the past years, the Nigeria government has demonstrated clearly that it is fighting the war against Boko Haram insurgency without a clear understanding of the sects world view. For a sect that morphed from a mere group of bandits to a group with international reach and armed with sophisticated weapons, it is imperative to understand its ideology.

Boko Haram was founded as a Sunni Islamic fundamentalist sect advocating strict form of Sharia law. It developed into a Salafist-Jihadist group in 2009, influence, perhaps by the Wahhabi movement. Members of the sect believe that their interpretation of the Quran is the 'true' Islam. Also they are convinced that this 'true' Islam in holistic and embraces all aspects of Muslims life in preparation for eternity. Initially, the founder of Boko Haram (Mohammed Yusuf) set out to establish Sharia government in conjunction with Borno State Government in northern Nigeria in the administration of Ali Modu Sheriff. In fact, speculation has it that "owing to its growing influence, Governor Sheriff courted the group and rode on its popularity to win his reelection in 2007" (Osun Defender, 2015, c.f, Osaretin, 2015).

The sect's main grudge against the Nigeria state is that the existing socioeconomic condition is both wrong and repressive. Primarily, it is wrong according to this perspective because it does not correspond to Islamic principles. Thus, in order to get rid of this condition of repression and wrong doing, Boko Haram seeks to establish an Islamic state. As self-styled Sunnis, they want to return Islam to what they view as the interpretation of first generation Muslims. This is a direct reference to the classical era of the caliphate. Arguably, the Caliphate represents one of the longest political institutions in human history. Though its lifespan started in 622 (right after the death of Mohammed) it was abolished by Mustafa Kenal in 1924. 
Furthermore, the need to 'rid' Nigeria of immoral and imperial Western domination and influences through the adoption of an Islamic path forms its basic objective. Therefore, to Boko Haram the solution to this problem lies in an embrace of Islamic teaching and an understanding that all 'true' Muslims compose a single cohesive community and must work together to resist the encroachment of corrupt Western influences. As such, any Muslim that works contrary to this dictum is classed with 'unbelievers'. To realize this goal, the group intends to leave no stone unturned.

\section{Discussion}

Social Movement Theory (SMT) posits the conditions under which grievances, which are plentiful, transform into mass movements aimed at social or political change. A very vita effect of the Boko Haram terrorist scourge on Nigeria is in the economic sphere. Indeed, as it becomes clear that nobody is safe as the terrorists can strike anywhere, economic activities have been on the decline and expansion plans are put on hold. For example, foreign investors, who use to flow at least 200 billion dollars a year into the Nigeria economy, no longer view the Nigerian economy as the safe haven (The Guardian, 2011).

Fundamentalism and Socio-Economic development in the North-Eastern Zone of Nigeria: a case of Boko Haram Movement

For the underdeveloped countries of the world, foreign investment means a lot, in fact since the proliferation of terrorism by Boko Haram in the north-eastern part of Nigeria; foreign investors have to think twice before coming into the countries to invest. It has also caused the military forces to take over the internal security of some states where the activities of Boko Haram terrorism were on the high side, for example declaration of state of emergency in Yobe, Adamawa and Bormo State. This on its own is another ignition point for another violent attack, either sporadic shooting with some identified Boko Haram members, thereby causing collateral damage at the expense of security of the citizens. It also put the military professionalism in doubt with regard to the role of the military in a nation.

In essence, the military force may not be at alert to notice external threats, losing the military combatant capability of battle field tactics, abuse of power by initiating military brutality in the civil society, engaging in unprofessional activities either enticed by the social activities etc. The Boko Haram terrorist scourge in contemporary national relations creates a public atmosphere of anxiety and it has undermined confidence in government.

The terrorists' unpredictability and apparent randomness makes it virtually impossible for government to protect all potential victims. The public demand protections that the state cannot give, this leads to frustrated and fearful citizens, this automatically has implications for citizens' loyalty to their government and when citizens' loyalty to their government is in doubt, then national stability is threatened. 
In Maiduguri, Borno State, where the sect originated from, the frequent bombing and clashes between Boko Haram and security agents have weighed down seriously on commercial and business activities in the city as many businesses have reportedly grumbled while many people have fled the state. The Maiduguri Monday market said to be the biggest market in the city is reported to have been seriously affected as hundreds of shop owners, especially southerners have closed their business and left the troubled city for their dear lives (Mohammed, 2007).

According to the Borno State Commissioner of information, it will take the state 20 years to recover from this current predicament it has found itself. The security challenges have negatively impacted on both private and public sectors of the economy as many business men and traders have relocated their businesses from the city. About 75 percent of the over three million Igbo businessmen and trader who engage in both small and medium scale businesses are reported to have fled to Abuja and the South-East due to the growing insecurity posed by the activities of Boko Haram insurgence (The Sun, 2011).

Federal government in 2013 raised the alarm over the devastating effect of Boko Haram insurgency on the region, warning that religious extremist will destroy the region if the activities of the Islamic sect are not curtailed. The then Information Minister, Mr. Labaran Maku, who spoke on behalf of the government, said that:

that the region needs peace and stability more than any other region in the country, particularly because the region is clearly lagging behind in term of infrastructure, education and other development indices, declaring that the North's economy is on the verge of collapse.

The greatest of these scenarios is the amount of funds being diverted to security issues and related matters. The aim is to enable the country meet the challenges of the present threat in the country. These funds can be best utilized in providing infrastructures in the country, like good roads, electricity and other vital amenities that will enhance the economic development of Nigeria. The irony is that while the government is striving towards capacity building, the Boko Haram menace is crumbling all the efforts.

\section{Theoretical Framework}

Theoretically, this study adopted the Social Movement Theory. Social Movement Theory (SMT) posits the conditions under which grievances transform into mass movements aimed at social or political change, which are rarer. McAdam, McCarthy \& Zald (1996: 4) describe three variables that scholars of SMT have identified as necessary conditions for social movements to emerge: political opportunities, mobilizing structures, and framing processes (Appleby, Gabriel and Emmanuel, 2003: 93). The political opportunities variable considers how political constraints and opportunities, 
particularly institutionalized politics, shape the emergence and success of social movements.

McAdam, McCarthy and Zald (1996: 6) were of opinion that the political opportunity variable focuses specifically on how changes in both institutionalized politics and informal groups with political power explain the emergence of social movements (Lustick, 1988). Mobilizing structures, the second variable, are "those collective vehicles, informal as well as formal through which people mobilize and engage in collective action" (Jennifer, 2011).

This variable builds off of two sub-theories: resource mobilization theory, which investigates the types of resources available to a group and how they are employed for mobilization; and social movement organizations, or how formal and informal groups and networks facilitate social movements (Mark, 2000: 19). The third variable, framing processes, considers the role that narratives and a sense of common purpose play in the formation of social movements.

Robert \& David (2000: 611) defines framing as "the conscious strategic efforts by groups of people to fashion shared understandings of the world and of themselves that legitimate and motivate collective action". This variable includes difficult-to-measure aspects of social movements such as identity, symbols, cultural values and norms, ideology, and shared meaning. McAdam et al. (1996: 4) "at a minimum people need to feel both aggrieved about some aspect of their lives and optimistic that, acting collectively, they can redress the problem".

Furthermore, McAdam et al. (1996: 4) hypothesizes that "cognitive liberation," or the hope that change is possible, is necessary for social movements to emerge and is part of successful framing. Framing processes, in other words, seek to understand how participants in collective action understand the problem and its solution. Taken together, SMT posits that political opportunities, mobilizing structures, and framing processes explain the necessary conditions that transform grievances into activism. As they take shape, social movements are highly visible collectives that aim to mobilize large numbers in order to effect change.

Social movements tend to draw on pre-existing groups and their networks to mobilize individuals into loosely affiliated collectives. Given their size and loose organizational structure, social movements usually have porous borders and individuals can join and leave the cause with relatively little cost. Framing processes create the conditions through which individuals that join the movement share common meaning and purpose (Gregg, 2016). If done correctly, framing creates a form of collective peer pressure, where individuals feel compelled to join up to be part of the experience (Rosenberg, 2011).

This point is further echoed by Williams (1995), who contends that the ideology of social movements needs to be rooted and understood in the wider society's culture in order to be effective. It is important to note that not all social movements are violent; in fact, many successful movements have been purposefully non-violent. Non-violent social movements also exist in Islam, 
although less well-known, and include the 20th-century Pashtun Badshah Khan's creation of 100,000 non-violent Khudai Khidmatgars to oppose British rule in the frontier region of South Asia, and the current-day non-violent philosophy of Sheikh Jawdat Saeed (Halverson, 2012). All of these movements have used religion to shape their non-violent social movements (Gene, 2010). When social movements turn violent, it is typically for a few key reasons.

First, political opportunities may be blocked, such as changing a policy or a country's leader through elections. In such cases, violence becomes one of the few remaining options for change. Second, social movements may turn to violence if the movement has become frustrated and some of its members feel violence is necessary to realize its goal. Third, violence can also be a tool used to push for negotiations with the opposition.

Finally, violence may also be used as a means to draw attention to the cause and inspire recruits. The goals of social movements are varied. They can range from mobilization to change a specific government policy to revolution. They can also mobilize to challenge social issues within a country or region. Regardless of the goal, social movements typically have specific objectives that draw the attention and support of elites, formal and informal organizations, and large numbers of individuals that agree with that immediate objective. Typically, once a social movement has achieved its goal, it demobilizes.

Religious social movements, a specific type of social movement, involve contention and mass mobilization that draw from religious resources and, in some cases, further religious goals. Christian (1996: 1) argues that not only is religion useful for mobilization. Driskell, Elizabeth \& Larry (2008: 294), religion also informs framing and the goals for which social movements fight more broadly. Resources include trained, legitimate leaders; pre-existing networks, organizational structures, and communications channels; and material resources such as money, buildings, schools, and hospitals.

Framing resources in religion include a moral framework to which adherents can relate; group cohesion and common identity; symbols and scripture that can be interpreted to justify the cause; and stories of persecution and perseverance that can create fortitude in difficult times (Christian, 1996: 1). Several scholars have used SMT to explain the rise of recent religious social movements around the globe. More recently, scholars have used SMT to explain the rise of the 2010-2011 Arab Spring, and the different roles that religion played in uprisings throughout several countries, including movements aimed at including religion in the goals for which groups are mobilizing (Bahgat \& Rabab, 2012).

Finally, it is important to note that social movements may draw on religious resources for mobilization, but the goals for which the movement is directed may not be religious. An example of this would be the Boko Haram movement, which used Islamic ideology as a source of mobilization and legitimacy, but did not have overtly religious goals. 
Gunning (2009: 156) offers a very good example of how social movement theory can help in explaining the act of fundamentalism. According to him, the real transformation for individuals to participate in this kind of activity often begins with participation with militant organizations through a process he called "political socialization". Here the individuals can be groomed, and over the course of time, can develop strong affinities with one another and to the course; so much so that they conceive themselves as inseparable from the group. Porta (2009) also observed in the Italian case in 1995 that radicalization and dispositions to participate in certain political violence among most of activists she interviewed developed as a strong bond, which emanated from socializations within the group.

According to her, people didn't just get motivated to participate just because of the groups' ideology or because they were members of the group. Rather, participation grew out of a processual dynamics, which may or may not take place when individuals get involved in groups (Porta, 2009). Often through actions of opposition and other forms of activism, individuals have investments in terms of their own identities and emotions that tend to create strong links with individuals within the groups. Often this bond is so strong that it motivates and continues to mobilize participants to adopt any means possible, as long as it protects their members' interests.

\section{Conclusion}

This study argues that the socio-economic and cultural ecology which contemporary Nigerian state presents help to sustain fundamentalist's ideology in terms of its organizational structure, group activities and sub-regional reach (Osaretin, 2015). This offers the key to the understanding of the support base of Boko Haram. The study also argues that the ideology which is at the heart of Boko Haram's philosophy is ultimately religious focused. Thus, the group appeals to religious sentiment to recruit members and sustain its momentum. Although conflicting narratives have been applied to explain the rise and transformation of Boko Haram in northern Nigeria, this study discovered that the primary concerns of the group center on the domination of Nigeria by Western influences, the poverty of the Nigerian people (particularly those that reside in northern Nigeria) and the declining morality it identifies in both the Nigerian state and the lives of individual Nigerians.

It also shows that Boko Haram's beliefs make adherent psychologically predisposed to use violence and surrender their lives to propagate the ideology of the group. Also the existing abysmal social conditions and frustration prevalent in north-eastern Nigeria help to promote extremism. This is further re-enforced by state neglect and falling standard of living which spur a violent backlash from Boko Haram. Nonetheless, the paper is of the view that there is a convergence between explanations which consider insurgency as a result of internalized radical Islamic beliefs (the type propagates by Boko Haram) and those that locate them in the externalized socio-economic conditions of the Nigerian state. 
On the apparent inability of the Nigerian state to stop Boko Haram in its trail despite the different official responses, the paper reveals that primarily, the missing link is that the Nigerian government has operated so far a oneinstant therapy to all the issues that mutually sustain the logic of the group. While the fire-for-fire approach is the most visible response of the Nigerian government, for a group whose recruitment and training lay important emphasis on the radicalization of its members and strong connection with a section of society, this policy option is insufficient to stop its expansionist tendencies (Osaretin, 2015). Rather, it would help to alienate those who feel connected to the peripheral sectors of society; who are sympathetic to the ideology, sentiments, idiosyncrasies and dialectical peculiarities and local circumstances and above all, who tends to create and preserved their socioreligious identity in Nigeria.

\section{References}

Abimbola, O.A. (2010) "Between Maitatsine and Boko Haram." Africa Today, 57(4): 99-118.

Adejumobi, S. (2011) Lessons Tunisia, Egypt and Sudan. Monday Guardian, 21 February.

Adepegba, A. (2011) "Police Arrest 51 over Post Election Violence". Punch, April 23.

Aldon, M. (1996) "The Black Church in the Civil Rights Movement: The SCLC as the Decentralized, Radical Arm of the Black Church." In Christian Smith (Ed.). Disruptive Religion: The Force of Faith in Social Movement Activism, New York: Routledge, pp. 29-48.

Appleby, R.S., Gabriel, A.A. and Emmanuel, S. (2003) Strong Religion Strong

Religion: The Rise of Fundamentalisms Around the World. Chicago: University of Chicago Press, pp. 93-98.

Armstrong, K. (2001) The Battle for God: A History of Fundamentalism. New York: Ballantine Books.

Bahgat, K. \& Rabab, E. (2012) Arab Spring in Egypt: Revolution and Beyond. Washington, DC: American University in Cairo Press.

Balogun, K.A. (1988) "Religious Fanaticism in Nigeria: Problems and Solutions" in the place of Religion in the Development of Nigeria. In K.A. Balogun and P.A. Dopamu etc., Ilorin, p. 328.

Brasher, B.E. (2001) The Encyclopaedia of Fundamentalism. New York: Routledge.

Christian, S. (1996) Disruptive Religion: The Force of Faith in Social Movement Activism. New York: Routledge, Constitution of the Federal Republic of Nigeria 1999, pp. 1-28.

Danjibo, N.D. (2009) Islamic Fundamentalism and Sectarian Violence: The "Maitatsine" and "Boko Haram" Crises in Northern Nigeria.

Dickinson, E. (2007) "Nigeria: Sharia Court Bans Satirical Play.” October 29. 
Driskell, R., Elizabeth, E. and Larry, L. (2008) "Faith and Politics: The Influence of Religious Beliefs on Political Participation." Social Science Quarterly 89(2): 294-314, 294.

Ezema, O.O. (2013) The socio-economic implications of the Boko Haram insurgence in Nigeria: 2009-2013. Department of Political Science Caritas University, Amorji-Nike, Enugu.

Constitution of the Federal Republic of Nigeria (1999) Promulgation Decree. no. 24 of 1999 Laws of the Federation of Nigeria.

Gene S. (2010) From Dictatorship to Democracy: A Conceptual Framework for Liberation. 4th U.S. Edition. Boston: The Albert Einstein Institution, pp. 1-7.

Gregg, H.S. (2016) Three Theories of Religious Activism and Violence: Social Movements, Fundamentalists, and Apocalyptic Warriors. Calhoun: The NPS Institutional Archive.

Gunning, J. (2009) Social Movement Theory and the Study of Terrorism. Critical Terrorism Studies. A New Research Agenda, In Richard Jackson, Marie B. Smyth and Jeroen Gunning (Eds.). London: Routledge. pp. 156177.

Halverson, J.R. (2012) Searching for a King: Muslim Nonviolence and the Future of Islam. Washington, DC: Potomac.

Hickey, R. (1984) The 1982 Uprisings in Nigeria: A Note. African Affairs, 83(331): 251-256.

Ibrahim, J. (1991) "Religion and Political Turbulence in Nigeria." The Journal of Modern African Studies, 29(1): 115-136.

Ibrahim, J. (1998) The State and Religion in Nigeria: Forces and Dynamics. Afrika Zamani, 5\& 6: 39-66.

Ilesanmi, S. (2001) Constitutional Treatment of Religion and the Politics of Human Rights in Nigeria. African Affairs, 100: 529-554.

Imo, C. (1995) Religion and the Unity of Nigeria. Uppsala Research Reports in the History of Religions. Uppsala: Almqvist and Wiksell International, pp. 6.

International Labour Organization (ILO) (2008) Global Employment Trends. Geneva: International Labour Office.

Jennifer J. (2011) Armed For Life: The Army of God and Anti-Abortion Terror in the United States. Santa Barbara: Praeger.

Johnson, T. (2011) "Boko Haram." Council on Foreign Relations. December 27.

Lustick, I. (1988) For the Land and the Lord: Jewish Fundamentalism in Israel. New York: Council on Foreign Relations Press.

Mark, J. (2000) Terror in the Mind of God: The Global Rise of Religious Violence. Third Edition, Berkeley: University of California Press, pp. 1929.

Maryjane, O. (1996) "Pastoral Mobilization and Contention: The Religious Foundations of the Solidarity Movement in Poland." In Christian Smith 
(ed.). Disruptive Religion: The Force of Faith in Social Movement Activism, New York: Routledge, pp. 67-86.

McAdam, D., McCarthy, J.D. \& Zald, M.N. (1996) Comparative Perspectives on Social Movements: Political Opportunities, Mobilizing Structures, and Cultural Framings. New York: Cambridge University Press.

Mohammed, A. (2007) "Shekarau Vows To Strengthen Sharia Legal Code." Daily Independent (Lagos), 16 May.

Nmehielle, V.O. (2004) Sharia Law in the Northern States of Nigeria: To Implement or Not to Implement, the Constitutionality Is the Question. Human Rights Quarterly, 26: 730-759.

Omemma, D.A (2012) Terrorism and the Challenges of Leadership: the Nigeria Experience. A Paper Presented to the Political Science Department, Caritas University.

Osaretin, I. (2015) Boko Haram and the Nigerian State: a Different Perspective. Globalism- Journal of Culture, Politics and Innovation.

Quintan, W. (2006) "Anatomy of the Salafi Movement." Studies in Conflict and Terrorism, 29: 207-239.

Porta, D.D. (2009) Social Movements, Political Violence, and the State. Cambridge: Cambridge University Press.

Robert, D.B. and David, A.S. (2000) "Framing Processes and Social Movements: An Overview and Assessment." Annual Review of Sociology, 26: 611-639.

Rosenberg, T. (2011) Join the Club: How Peer Pressure Can Transform the World. New York: Norton.

Ruthven, M. (2005) Fundamentalism: The Search for Meaning. Oxford: Oxford University Press.

Soludo, C. (2007) Preserving Stability and Accelerating Growth. Abuja: Central Bank of Nigeria, January.

Suleiman, T. (2009) The Plot to Islamise Nigeria. Tell, Lagos, 30 November, pp. 19-23.

Tell (2001) Lagos, September 24, p. 27.

Guardian (2011) Government Lists Boko Haram to Economy: Defence Chief Meet. February 9.

Guardian (2003) Lagos, October 29.

The Nation (2011) Emergency Unnecessary: It is not an Option to Flush out Boko Haram Elements in Borno State. July 3.

The Sun (2011) Divergent View on Amnesty for Boko Haram, June 31.

Williams, R.H. (1995) "Constructing the Public Good: Social Movements and Cultural Resources." Social Problems 2(1): 124-144.

Woodberry and Smith, C. (1998) "Fundamentalism et al: Conservative Protestants in America." Annual Review of Sociology, 24: 25-56. 